\title{
Social and Cultural Determinants of Child Labor in Pakistan
}

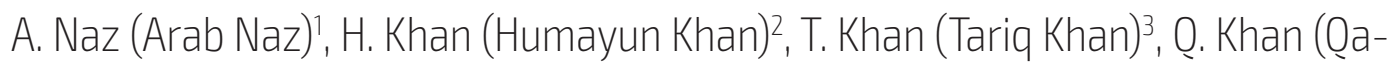
isar Khan) ${ }^{4}$, W. Khan (Waseem Khan) ${ }^{5}$

${ }^{1}$ Department of Sociology University of Malakand, Khyber Pakhtunkhwa,

\section{Original Article} Pakistan

${ }^{2}$ M.Phil Scholar Sociology/Social Work, University of Malakand, Khyber Pakhtunkhwa, Pakistan

${ }^{3}$ Assistant Professor English University of Malakand, Khyber Pakhtunkhwa, Pakistan

${ }^{4}$ Associate Professor, English University of Malakand, Khyber Pakhtunkhwa, Pakistan

${ }^{5}$ Lecturer Sociology University of Malakand, Khyber Pakhtunkhwa, Pakistan

\section{E-mail address:}

arab_naz@yahoo.com

\section{Reprint address:}

Arab Naz

Department of Sociology

University of Malakand

Khyber Pakhtunkhwa

Pakistan

Source: Clinical Social Work and Health Intervention

Pages: $80-92$
Volume: 10

Cited references: 42

Issue: 2

\section{Reviewers:}

Josef Suvada

Ministry of Health of the Slovak Republic, Slovakia

Daria Kimuli

Catholic university of Eastern Africa, Nairobi, Kenya

\section{Key words:}

Issues. Relations. Social capital. Supply. Demand. Poverty.

\section{Publisher:}

International Society of Applied Preventive Medicine i-gap

CSWHI 2019; 10(2): 80 - 92; DOI 10.22359/cswhi_10_2_11 C 2019 Clinical Social Work and Health Intervention 


\section{Abstract:}

Child labor has serious consequences upon children, their families and even on the larger spectrum of society as well. The researchers have predominantly utilized quantitative research design along-with qualitative discussion and a survey of the various mechanical workshops in Batkhela city was conducted in September 2013. For quantitative analysis, a list of all the population of children was prepared i.e. 4355 children working in different capacities (average 02 to 08 children were found working) and a sample of 200 children age 05 to 18 year were selected randomly giving maximum representation to the mentioned age group. The data was collected by using an interview schedule and the information was then processed through different phases (i.e. editing, classification, and presentation) through SPSS (Version 18) and in Excel and MS Word for tabulation and charts presentation. Through ChiSquare Test, the association of various determinants of child labor has been analyzed at the 5\% level. Besides, 'Human Capital Theory' and 'Demand and supply Factors' have been kept as theoretical orientation. The data shows that child labor in the area is the outcome of various social, cultural factors including joint family system, divorce, familial conflicts, agriculture-based-economy and large family size.

\section{Study Background}

Child labor has serious consequences that stay with the individual and society longer than their years of childhood. Young workers not only face dangerous working conditions but also encode long-term physical, intellectual and emotional stress. They face an adulthood of unemployment and illiteracy (United Nations Secretary General, Kofi Annan, 1999, Okpukpara, B.C, \& Odurukwe, N., 2003). The literature support that such work deprives children of their childhood, potential and dignity; and is harmful for their physical and mental development shall be known as child labor (Mazhar, 2008). In this context, child labor refers to work that is mentally, physically, socially, or morally hazardous to children and/or interferes with their schooling by depriving them of the opportunity to attend school, obliging them to leave school prematurely or requiring them to combine school attendance with an excessively long and heavy workload (ILO, 2005, Program for the Elimination of Child Labor, 1999, CRC, 1989, Art. 32). Besides, there are opinions regarding child age and work whereas child laborers would include children younger than the age of 12 who are economically active; engaged in more than light work; engaged in the worst forms of child labor in which they are enslaved, forcibly recruited, prostituted, trafficked; forced into illegal activities; exposed to hazards (ILO 138, 1973; 182, 1999, UNESCO, 2008).

In many countries, there is a cultural and situational need for child work i.e. in an agricultural economy children are mostly engaged in farms, markets, streams, paidjobs with parents to learn and to integrate them into the society (Nnaemeka, 2011). Because, to face the challenges of life in the future there are needs and requirements, children shall not be included in child labor (Okafor, E. 2010). Such work of children 
is for sustaining the self - survival; maintaining familial life; supporting family at the loss of their own personal growth and development (Bhargava (2002). Such works are considered useful giving practical education and trainings, etc. (Mazhar, 2008). Ray (2000) in this context is the view that children working along with their parents in household chores, family enterprises or agriculture may be helpful in developing capabilities and learning potentialities in children which usually are considered socially valuable qualities mostly linked with various social and cultural factors and indicators. Mazhar (2008) argues that the low rates of productivity growth further contribute to the intergenerational poverty trap and hamper economic growth that ultimately is a leading factor in hazardous child labor (ILO Convention 182: 1999).

The trend of child labor in third world is mostly associated with poverty as serious determining force (Mazhar, 2008) sometimes, with families having low educational background and disadvantaged position (International Labor Organization, 2008, Psacharopoulos, G. and Woodhall, M. 1997). Further, child hawking involve a wide range of labor in Nigeria and the South-East zone where children hawk a wide range of cheap articles, edibles and products such as sachet water, plantain chips, bread, biscuits, okpa, ugba, fruits, vegetables, wears, newspapers in the streets and along the roads especially at damaged portions of roads where motorists and other road-users are constrained to slow down due to the bad condition of such roads (Nnaemeka, 2011).

Most of the child labor is bonded labor which refers to situations where a child's labor services are offered in exchange for a loan (Genicot.G., 2000) and such practice occur for a child alone or for the whole family as well. Millions of people are still held in bonded labor around the world (Human
Rights Watch Asia, 1996, Mazhar, 2008). He or she gets up very early in the morning and begins his or her work by fetching of water from a nearby well, balancing the heavy jug on his or her head as he or she returns, prepares breakfast, serves it, work their remaining jobs till evening and late in night (Okafor, 2010). Thus as a problem, child labor is concerned with damaging a child personality and future life as well and is mostly associated with various socio-cultural, economic and other multifaceted determinants.

\section{Argument and Justification}

The issue of child labor is one of the major concerns of the third world as various factors are involved in the promotion of child labor. Children faces higher risk and hazardous conditions in those places where they are involved in child labor activities. Among the various issues, child labor in an early age not only destroys the learning capabilities of the children but also may lead to lower down the earning capacities as well as educational loses in the future (Psacharopoulos, 1996). Bhargava (2002) also indicated that child work in the early age have multiple effects on the food and nutrition of the children as well as deprived children of education. Child labor has been regarded as an obstacle in child's education as well as prosperity in life while child labor is regarded as key factor in achieving Millennium Development Goals (MDG). Such internationally approved principles recommend the removal of child labor for better education and prosperity of the nation and give emphasis access to basic education, and defining the age and work for a child to perform (ILO Convention 182, 138 and Heady, 2003). In this regard, the current research explores the various social and cultural determinants responsible for child labor in Pakistan, particularly in Pakhtun society with reference to 
Batkhela city at Malakand Davison in Khyber Pakhtunkhwa. The study focuses on the conditions that compels children towards labor and are becoming disadvantageous in many of the aspects of life including economy, education, health, recreation and even social and physical development along-with moral and psychological growth. Specifically, the concern of the current study is upon such determinants associated with social structure, familial relations, divorce and even familial conflicts that seem to be playing a pivotal role in increasing child labor. The specific objectives of the study include:

\section{Objectives of the Research}

1. To know about the socio-cultural determinants of child labor in machine workshops

2. To assess the role of broken family, divorce, marriage and familial conflicts in child labor promotion

\section{Hypotheses of Research}

This research seeks to analyze the following potential hypotheses:

H-1: the normative social structure and traditional way of living contribute in child labor

H-2: Family disorganization, divorce among the parents and familial conflicts are the major determinants in promoting child labor

\section{Methodological Procedure and Theoretical Framework}

A survey of the various mechanical workshops in Batkhela city was conducted in September, 2013 (which was completed in two months) for obtaining firsthand information regarding the total number of workshops, number of children, familial status, conflicts and other relevant information. For quantitative analysis, a list of all the population of children was prepared i.e. 4355 children working in different capacities (average 2 to 8 children were found working) and a sample of 200 children of all age 5 to 18 year were randomly selected giving maximum representative to all age groups. The data was collected by using both aspects of qualitative and quantitative research where the quantitative approach had generated information about various aspects of child labor, determinants through interviews using an interview schedule from children while the qualitative methods have been utilized in the form of observations, case studies, comparison and other aspects related to the literature obtained and discussions made over the field data as well as other parts of the research as adopted by Gray- (2004), Mazhar, (2008) and Kottak (1991). The data processing was performed in various phases (i.e. editing, classification, and presentation) through SPSS (Version 18) and even in Excel and MS Word for tabulation and charts presentation. Through Chi-Square test, the association of various determinants of child labor have been analyzed at the 5\% level. The current research has been framed under 'Human Capital Theory' given by Tharenou, P., Saks, M. and Moore, C. (2007). The second major work is 'Demand and supply Factors' as the dominant theoretical orientation. The approach has also been supported by ILO (2006), Goode (1959:147), Kiker, (1966:485), Baland and Robinson, (2000), Canagarajah and Nielsen (2001) etc. Besides, support has also been taken from the work of Amin, Shakil, M, Rives, M, Janet (2004)- Grimsrud, (2003), Jafarey, (2002), Silvers, J. (1996), Baland and Robinson, (2000), Rosenzweig, M. 1982. Lavy: 1996, Nielsen:1998, Grootaert :1998). 


\section{Results of the Study:}

\section{Socio-Cultural Poverty, Norms, Values and Child Labor}

With regard to the current study, the research community possess and have its own social and cultural structure. The area is mainly dominated by traditionalism where majority of the subject respondents were of the opinion that the lives of the people are governed by the normative and traditional values of Pakhtun social structure. Pakhtunwali (traditional codes or way of life) dominates lives and thus it is believe that a child shall respect and obey the orders of their elders and shall work with them in the field, market or any place they deserve. Similarly, the field research provides details about the family structure. The majority of the population is living in joint families. The number of person in the household remains large and thus mostly is dependent on the earning of many hands in the family. There are many dependent members in a family and even females have to work hard to support their household. It is culturally believed that sending a child to the labor market is much better than their spending many years on getting education. Similarly, the major portion of the respondents belonged to an agriculture economy, working in fields of the rich people. During time of harvest and reaping, they strongly need the help of many hands, particularly of children. Thus, children are socially and culturally responsible to work in field and other areas.

Many of the cases were found during interview among the children that they are busy both at home and in the workshop. Even sometimes, they can't decide what to opt for work and which shall be the priority at first. The majority of children were found busy doing multiple activities in a day i.e. work in machine shop, bringing various vehicles, to clean, give services to the elder (owner of the workshop) along-with helping their parents at home. Such schedules rigorously comple them to work for more than 15 hours a day which is socially and legally not acceptable. In this context, one of the interviews noted in the field can best describe the actual situation. The respondent was questioned about the various social and cultural norms, his schedule and activities in a single day. The summary is given here:

It is our familial and cultural norm to act according to the order issued by our elders. I live in joint family of 11 members in a small rented house. My three elder bothers are working in different areas i.e. one is a tailor, the other work on fixed pay at a shop while the elder is helping my father in fields and family matters. All of us are busy in different jobs from morning till evening i.e. I wake up early in the morning and bring milk and other daily items from the bazaar. After my breakfast, I help mother in various activities and then come to the mechanical workshop. Here I am busy in various tasks including bringing different material and items, washing and cleaning of parts of engine, vehicles, service etc and sometime to pay visits to the house of owner to bring items of daily use from the bazaar. I am also in touch with my father and brother in the field and providing services when needed to them. Many times, I came across with work for more than 15 hours a day and even on a single holiday I have no spare time to play with friends.... (Extract from an interview).

The field data obtained through the interview schedule also indicates that socio-cultural factors and poverty have much to do with child labor promotion in the area. The data has been given in the following diagram 


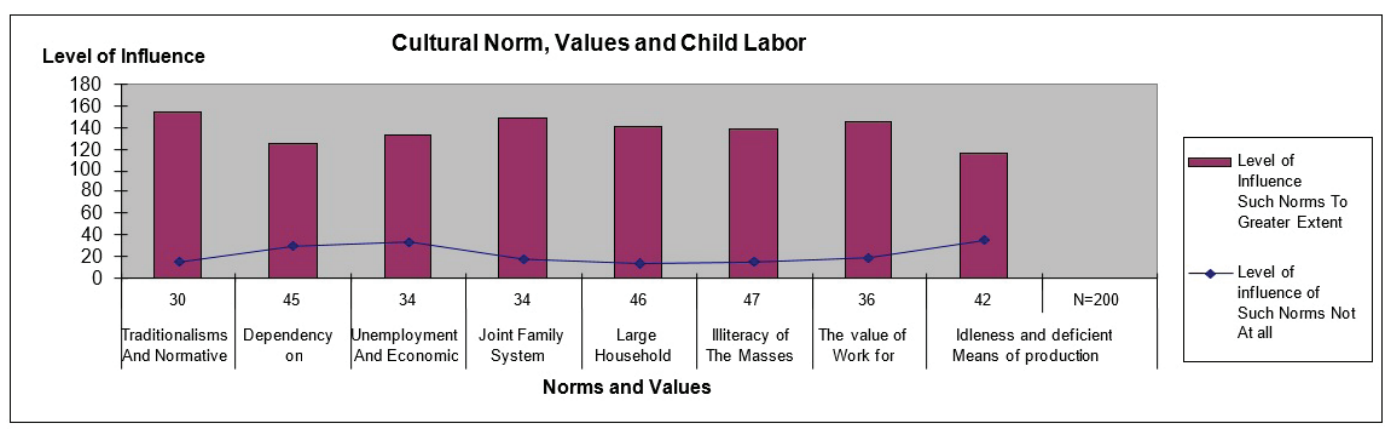

\section{Household Structure and Child Labor}

With respect to the current research study, it has been observed that dominant Pakhtoon traditional family joint family system is in vogue in the area and it is considered as geatest source of social insurance (Naz, A. 2011, and Naz, et al. 2012). The majority of the research participants are residing in joint family system where they bear common expenses not only for household activities. Further, the field observations shows that this system is a factor in the promotion of child labor in the area because economic support to family is hard to meet with earning of a single person. The field information support the literature and it is noted that majority of the elements i.e. study population belongs to the agricultural background and most of the time such children remain busy in field with the parents to earn for their family and thus is a source of child work in future.

Analysis of the field research and its discussion with the population under study, most of the hypothesis that considered the large family size i.e. joint or extended as the source of child labor in the area. The house hold structure can give a rise and fall in the ratio of child labor and most of the respondents agreed upon the notion that household's structure (in case of large family) put human being in a struggle for survival. The cases analyzed were the true examples and the information narrated by one of the child is given as under:
The family members are more than 13 where my parents, uncles, grandparents, brothers and sisters are included. My father work in fields and is helped by my mother and uncles while all the children also contribute in this matter at time of reaping and harvesting. The limited income resources of the family push all of us to go to works and to earn for our family. Only one of my brothers and two sisters are going to schools but schooling is supported by the neighbors. The incidents of quarrels, conflicts upon petty issues and visit to a doctor are the routine activities in our family... (Statements from an interview)

Analysis of field data and other such details confirm that child labor among the local community is due to the structural and functional requirements of the people. People send their children into the labor market due to their familial and household requirement. Most of the children in the machine workshop were of the opinion that majority of the work force of children belonged to large families with very low economic resources and even to them, their mother and sisters most of the time are engaged in the earning process. The information with regard to the household size and its impact on child labor is given here: 


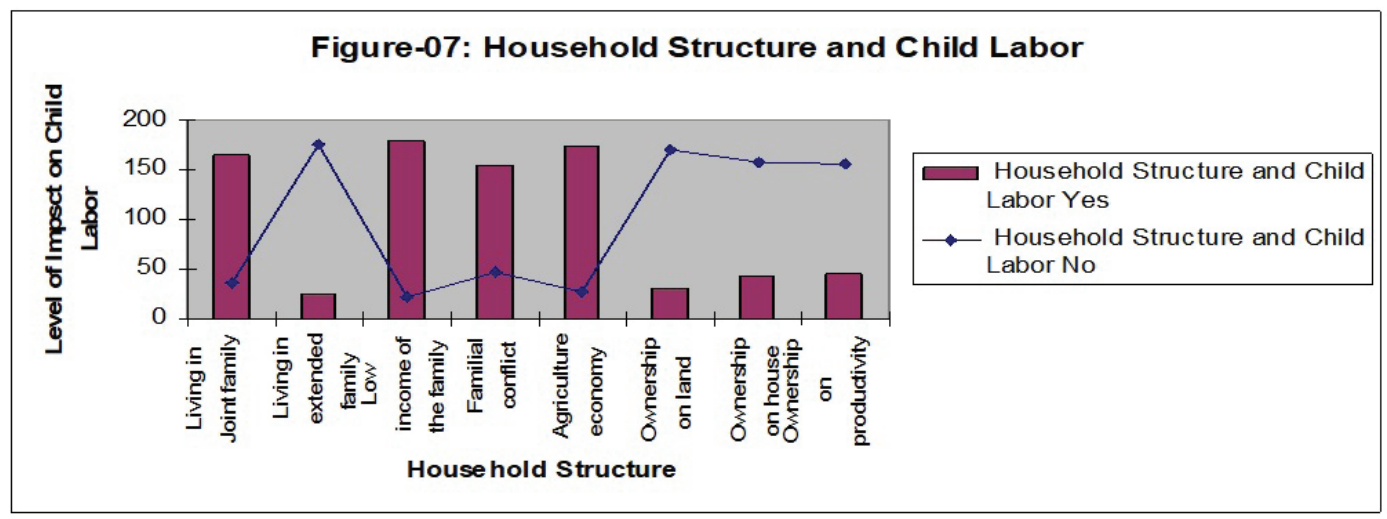

\section{Family Disorganization and Child Labor}

The current study and the field research about the role of family disorganization in child labor promotion have been analyzed through in-depth interviews with children and their immediate teachers. Cases with particular emphasis on the issue of family disorganization are given with reference to the secondary data and prove that family disorganization is playing a dominant role in child labor in the area under study. The concept of family disorganization in the field data has multiple directions. Among them, familial conflicts are the major concern where the field information is supporting such disputes to a major extent. Most of the children are of the opinion that there is conflict among their parents and most of conflicts are the outcome of a lack of the family necessities. According to interviews conducted in the field, majority of familial conflicts are associated with loans and dependency on economic benefits obtained through loans from well off people. Howev$\mathrm{er}$, the data indicates that the return of such loan then become impossible for family elders which ultimately is responsible for familial disorganization in the form of parental conflicts. Similarly, the field data and interviews with the owner of the workshops further confirm that most of the time, conflicts on such pity issues become severe and may lead to gravity in the parent's relations or may sometimes become an easy excuse for separation. During the field visits, one of the cases of family separation was observed seriously and can authenticate family disorganization as a factor in child labor. The narration of the mentioned case has been given:

Our family is very poor and we have no such income generating resources in hand. Our family is surrounded by miseries in the form of loans, economic dependency, and other domestic issues related to education, medical treatment, and marriage of the sisters and even expenses of the household. We have taken daily item from the shops and also from the main bazaar regarding our household expenses and the loan has currently crossed the figure of Rs.25,000/where the shopkeepers visit regularly to our house for getting their loan back. Although, we are trying to combat with the issue but still we are far behind to return the amount. Besides, there are regular conflicts in our family and even my mother has left for home many times and stayed with her own parents...... (extract from an interview)

In the context of family disorganization, field research links such disorganization of unhappy family relations among couples. An unhappy and conflicting atmosphere created by social issues i.e. income, medical 
facilities, problems in child socialization, education provision and its non-fulfillment create a scenario of dissatisfaction among husband and wife that ultimately is a leading factor in throwing children into the worst form of child labor. Field research with regard to marriage dissatisfaction has been observed from field data and most of the children were of the opinion that there is conflicting atmosphere inside the family and even conflicts on minor issues among their parents. Similarly, marriages among their parents have shown many time overt and even violent kind of behavior leading to separation of couple. Besides, even there occurs a fight between parents that even many times make wounds on the body of the mother as proclaimed by many of the respondents. In a similar context, one of the respondents told the story of their parents fight as narrated in the following lines: we feel better in our workshops than the house. (extract from an interview).

Field data and many other aspects analyzed indicate that family organization play an important role in child education and promotion of excellence in character building among them. However, while questioning the children, a majority of them were of the opinion that the reason of harshness and disobedience among many of the laborer children is associated with family disorganization and disharmony among parents. Aspects of organization and harmony are found missing in many of households of the area leading towards child labor and child work as well. The information has been graphically presented in figure-09 below while the tabular data has been presented in table-09 (See Annexure-A).

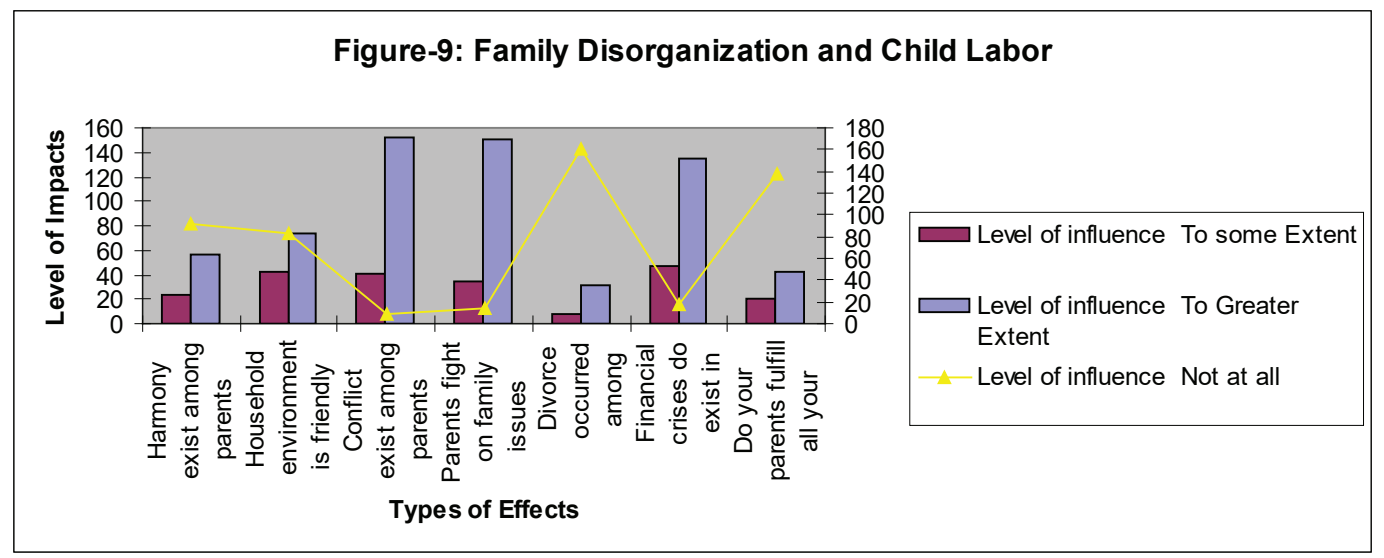

My father and mother have no ideal relations with each other and many of the times, they we have confronted conflicting situations with one another. Similarly, even children at the home feel exhausted of their conflicts because the exchange of words among them is very harsh and even the beating of my mother make injuries on her body as well. There is no harmony at the home and

\section{Discussion over Results}

The information and findings of the test statistic with regard to hypothesis-1 prove that social and cultural determinants, i.e. poverty, norms and values, household size and structure are the major reason in child labor. The test statistic i.e. (Chi-Square application) about the social norms and values on the $.05 \%$ of confidence level indicates 
that the proposed hypothesis is accepted for the data grouped under various variables. The Pearson Chi-Square Test confirmed to the value of 333.342, D.F. 04 and the value of $\mathrm{P}$ is .000 shows significant association of norms and values with child labor promotion. In a similar way, the household size has been evaluated with chi-square and the values for the table have been obtained through SPSS which confirm the association for household size and child labor. The value of chi-square results is 156.344 ., D.F. 05 and the value of $\mathrm{P}$ is .000 that shows a significant association between household size and child labor with ratio of .05\% confidence interval. Similarly, data regarding hypothesis-2 which is about family disorganization, divorce and broken family system, conflict among parents are further analyzed. The value of the Chi-Square test indicates that there is significant association between family disorganization, divorce and parental conflict and child labor where the association of family disorganization and child labor has been proved with $\mathrm{P}=.000$ D.F. 4, chi-square value is 135.222 and the level of significance i.e. $.05 \%$ and $95 \%$ confidence interval validate the hypothesis.

\section{Conclusion and Recommendations}

On the basis of the data obtained from the field, their analysis and statistical conclusion with theoretical discussion, the researchers recommend the following:

- Research confirms that there are various social, cultural determinants in the area where by as it is impossible to eradicate child labor in such a rigid atmosphere. However, through propagation of education as the basic right of a child and its implementation through the concern authorities can reduces the hold of such aspects to a greater extent.

- Youth and children are easy victim in the early age and if we look at the area, there is no importance given to education in general, child education in particular. An image of the educated community shall be propagated and the age limits shall be strictly observed in machine workshops as well as other such places.

- Familial organization in the local area is disrupted and there are conflicts among family members on issues related to family income and other such minor issues. Besides, there are more chances of divorce and separation among family members which deprive children not only from parental care but also push them in the labor market. Such issues shall be treated according to the custom and traditions, the law enforcement agency shall be involved to take care of the matter.

- Similarly, family coordination is also necessary the expenses shall be made according the priority of the family. In this regard, a proper saving scheme shall be initiated to keep some money for difficult times and shall be utilize for child education.

\section{References}

1. ALECTUS, M. PETER, D. JANET H. MICHAELLE DE K. JOOST K, PETER M (2004) Child Labor. Geneva: International Labor Office.

2. AMIN S, SHAKIL M, RIVES M JANET (2004) 'Poverty and Other Determinants of Child Labour in Bangladesh', Southern Economic Journal, vol. 70, No.4, P- 876892, retrieved April 18, 2008, from http:// www.jstor.org/stable/4135277.

3. ANKER R (2000) The Economics of Child Labor: A Framework for Measurement." International Labor Review. Vol. 139 (3).pp. 257-280.

4. BACHMAN S L (2000). A New Economics of Child Labor: Searching for Answers behind the Headlines. Journal of International Affairs Vol.53 (2):pp. 545-572. 
5. BAILEY DK (1978) Methods of Social Research. Collier Macmillan. London. p.26.

6. BALAND J M, ROBINSON J A " "Is Child Labor Inefficient?" Journal of Political Economy. Vol. 108 (4):pp. 663-679.

7. BASU K, SANGHAMITRA D, BHASKAR D (2010) Child Labor and Household Wealth: Theory and Empirical Evidence of an Inverted-U." Journal of Development Economics. Vol. 91 (1):pp. 8-14.

8. BASU K, PHAM HOANG VAN (1998) The Economics of Child Labor. American Economic Review. Vol. 88 (3). Pp. 412427.

9. BASU K, GRANCE G, STIGLiTZ J E (2000) Household Labor Supply, Unemployment, and Minimum Wage Legislation', Policy Research Working Paper, No.2049, The World Bank.

10. BASU K (1999) Child Labor: Cause, Consequence, and Cure" in Journal of Economic Literature, Vol. 37.(3). 1083-1119.

11. BHARGAVA P (2003) The Elimination of Child Labour: Whose responsibility? Sage Publications India Ptv. Ltd. B-42, Panchsheel Enclave, New Delhi.

12. BINDER M, SCROGIN D (1999) Labour Force Participation and Household Work of Urban School Children in Mexico: Characteristics and Consequences. Economic Development and Cultural Change Vol. 48 (1). pp. 124-153.

13. BOYDEN J (1991) Working Children in Lima Peru. In W.E. Myers (ed.) Protecting Working Children, Zed Books, London.

14. BROWN D (2002) The Determinants of Child Labour: Theory and Evidence, Discussion, Working Paper No.486, School of Public policy, The University of Michigan. http://www.fordschool.umich.edu/rsie/ workingpapers/Papers476-500/r486.pdf. Retrieved on September 25, 2013.

15. BROWN D, ALAN V D, ROBERT M S (2002) The Determinants of Child Labor: Theory and Evidence. Ann Arbor, MI: The University of Michigan.
16. CANAGARAJAH S, NIELSEN H (2001) 'Child Labour in Africa: A Comparative Study', Annals of American Academy of Political and Social science. Children's Rights, Sage Publications, Inc. in association with the American Academy of Political and Social Science. Vol. 575. http://www.jstor.org/ stable/1049181 Retrieved on October, 2013.

17. CHAUDHRY S M, KAMAL S (2005) Introduction to statistical theory. (Part 2). Lahore:Ilmi Kitab Khana.

18. CORSON D (1992) Language, Gender, and Education: A Critical Review. Linking Social Justice and Power. Gender and Education. Vol. 4 (3). October. Pp. 229-244.

19. CRISTINA M S (1994) La significación social del trabajo infantil y juvenil en América Latina y el Caribe. Revista Colombiana de Educación. Vol. 28.p. 45.

20. DELAP E (2001) Economic and Cultural Forces in the Child Labor Debate: Evidence from Urban Bangladesh," The Journal of Development Studies. Vol. 37 (4).pp.15-16.

21. FARES J, DHUSHYANTH R (2007) Child Labor across the Developing World: Patterns and Correlations. Washington D.C.: World Bank.

22. FYFE A (2004) Child Labor Policy Option, ed. Kristoffel Lieten and Ben White, Child labor and education; Revisiting the policy debate, Aksant Academic Publishers, Cruquiusweg 31, NL-1090AT Amsterdam.

23. GENICOT G (2011) Child Bonded Labour; http://www9.georgetown.edu/faculty/ gg58/CBL.pdf. Retrieved on September, 12, 2013.

24. GHAYUR S (1997) Labor Market Issues in Pakistan: Unemployment, Working Conditions, and Child Labor. The Pakistan Development Review. Vol. 35 (4). Pp. 789-803.

25. GOODE R (1959), 'Adding to the Stock of Physical and Human Capital', American Economic Review, vol.49 (2).

26. GRIMSRUD B (2003) 'Millennium development goals and Child Labour, Understanding Children's Work', Understanding 
Children's Work an Inter- Agency Research Cooperation Project, Retrieved May 5, 2008, from http://www.ucw-project.org/pdf/publications/mdg_and_cl.pdf.

27. GROOTAERT C (ed.) (1998) 'Child Labour in Cote d'Ivoire, In the Policy Analysis of Child Labour: A Comparative Study', Washington, D.C: World Bank.

28. GROOTAERT C (1998) Child Labor in Côte d'Ivoire: Incidence and Determinants. Washington D.C.: World Bank.

29. GROOTAERT C, KANBUR R(1995) Child Labour: An Economic Perspective. International Labour Review. Vol. 134 (2). Pp.187203.

30. HEADY C (2003) 'The Effect of Child Labour on Learning Achievement', Science Direct-World Development, p. 1-18, retrieved February 28, 2008, from http:// www.sciencedirect.com.orl.iss.nl/science? $\mathrm{ob}=$ ArticleURL\&_udi=B6VC6-47MCFD.

31. HUMAN RIGHTS WATCH ASIA (1996) www.humnrightswatch.co.

32. INTERNATIONAL LABOR ORGANIZATION (2005) Combating Child Labor in Carpet Industry ( Phase II). International Programme on Elimination of Child Labor, Islamabad, Pakistan. http://www.ilo.org/ public/english/region/asro/newdelhi/ipec/ responses/pakistan/p2.htm. retrieved on October 2, 2013.

33. INTERNATIONAL LABOR ORGANIZATION (1996) Child Labor: Targeting the Intolerable. Geneva: International Labor Organization. P. 15.

34. INTERNATIONAL LABOR ORGANIZATION (2006) What is Child Labor? http:// www.ilo.org/ipec/facts/lang-- en/index.htm. Retrieved on September, 23, 2013).

35. INTERNATIONAL LABOR ORGANIZATION (2008) Sub-regional information System on ChildLabour.IPEChttp://www. ilo.org/public/english/region/asro/newdelhi/ipec/responses/pakistan/index.htm. Retrieved on June 3, 2013.
36. INTERNATIONAL LABOR ORGANIZATION (l'013) "Convention 138: Minimum Age Convention," http:/www2.ohchr.org/ english/law/ageconvention.htm. Retrieved on September 23, 2013.

37. INTERNATIONAL LABOR ORGANIZATION (2013) "Convention 182: Convention Concerning the Prohibition and Immediate Action for the Elimination of the Worst Forms of Child Labor," http://www.ilo.org/ public/english/standards/relm/ilc/ilc87/comchic.htm. Retrieved on September 23, 2013.

38. INTERNATIONAL LABOR ORGANIZATION (2013) "Ratifications of the Fundamental Human Rights: Conventions by Country," http://www.ilo.org/ilolex/english/ docs/declworld.htm. Retrieved on September 23, 2013.

39. INTERNATIONAL LABOR ORGANIZATION (2013) "Ratifications of the Fundamental Human Rights: Conventions by Country," http://www.ilo.org/ilolex/english/ docs/declworld.htm. Retrieved on September 23, 2013.

40. INTERNATIONAL LABOR ORGANIZATION-IPEC (1999) National Program on the Elimination of Child Labor in Nigeria. www.ilo.org/wcmsp5/groups/.../wcms publ_9221124169_en.pdf. Retrieved on September, 11, 2013.

41. JAFAREY S (2002) Child Labour: Theories, Policy and Evidence, JEL: H52, 010,016, p.26. http://www.jstor.org/stable/4135277. Retrieved on April 18, 2013.

42. KAMBHAMPATI U S, RAJI R (2006) Economic Growth: A Panacea for Child Labor?. World Development. Vol. 34 (3 ). Pp.426-445.

43. KHAN W (2011) Pakhtun Social Organization and Women's Decision Making. Unpublished M.Phil Thesis. Department of Sociology, University of Malakand, KP. Pakistan.

44. KIKER B (1966) 'The historical roots of the concept of human capital', Journal of Political Economy, Vol.74, no.5, p. 485. 
45. KOTTAK C P (1991) Anthropology. The Exploration of Human Diversity. McGraw -Hill Inc. p.24.

46. LAVY V (1996) 'School Supply Constraints and Children's Educational Outcomes in Rural Ghana', Journal of Development Economics, vol. 10, p.291-314.

47. LEVY V (1985) Cropping Pattern, Mechanization, Child Labor, and Fertility Behavior in a Farming Economy: Rural Egypt. Economic Development and Cultural Change. Vol. 33 (4):pp. 777-91.

48. MACIONIS J J (1993) Sociology (4th ed). Prentice Hall. Englewood Cliffs New Jersey.

49. MAZHAR Z A (2008) Child Labor in Pakistan: Including the Excluded. Subsidized Education and Subsidy: Tools to Combat the Worst Forms of Child Labor. Master Thesis in Developmental Studies; Institute of Developmental Studies, Graduate School of Development Studies. The Hague, the Netherlands.

50. NAJEEB M S, PATRINOS H A (2008) A Positive Stigma For Child Labor?.Washington D.C.: World Bank.

51. NATIONAL HUMAN DEVELOPMENT REPORT (2008-2009) Achieving Growth with Equity". http://hdr.undp.org/en/reports/ global/hdr2010/news/africa/. Retrieved on $24^{\text {th }}$ July, 2013.

52. Naz, A. (2011). Socio-cultural and Political Constraints in Gender Development. Unpublished PHD Dissertation. Department of Anthropology QAU Islamabad, Pakistan.

53. NAZ A, HAFEEZ R, KHAN W, DARAZ U H (2011) Inflation: The Social Monster: Socio-Economic And Psychological Impacts Of Inflation And Price Hike On Poor Families Of District Malakand, Khyber Pakhtunkhwa, Pakistan. International Journal Of Business And Social Sciences. Vol. 2 No. 14. pp. 285-295.

54. NIELSEN H (1998) 'Child Labour and School Attendance in Zambia: Two Joint Decisions', Working Paper No. 98-15, Centre for Labour Market and Social Research, Aarhus, Denmark.
55. NNAMEKA N C (2011) The Challenge of Child Labor to the Achievement of MDG2: Case Study of South-East Nigeria. Master Thesis, Department of Economics, Universita' Degli Studi “Roma Tre".

56. OKAFOR E E (2010) Child Labor Dynamics and Implication for Sustainable Development in Nigeria. Journal of Sustainable Development for Africa. Vol. 12 (5).

57. OKPUKPARA B C, ODURUKWE N (2003) Incidence and Determinants of Child Labor in Nigeria, Implications for Poverty Alleviation. Journal of Economic Policy. Vol. 10 (2).pp.123-136.

58. OLOKO S B A (2004) Child Labor in Nigeria: Continuities and Transformation. University of Lagos Press.

59. PSACHAROPOULOS G, WOODHALL M (1997) Education for Development: An Analysis of Investment Choice. New York Oxford University Press.

60. PSACHAROPOULOS G (1997) Child Labor Versus Educational Attainment: Some Evidence from Latin America" in Journal of Population Economics. Vol.10. pp.286-337.

61. QUIROZ L (2008a) Child Labor and Quarrying in Guatemala. Amsterdam: International Research on Working Children.

62. QUIROZ L (2008b) Child Labor in the Coffee Sector of Guatemala. Amsterdam: International Research on Working Children.

63. RAMÍREZ P W, MIRIAM DE C ERWIN D, CÁCERES A (2000) Informe nacional sobre trabajo infantil en Guatemala. Guatemala City: International Labor Organization. Washington DC.

64. RAY R (2000) Child Labor, Child Schooling, and their Interaction with Adult Labor: Empirical Evidence for Peru and Pakistan. The World Bank Economic Review Vol.14 (2):pp. 347-67.

65. ROSENZWEIG M (1982) 'Educational Subsidy, Agricultural Development, ad fertility change', Quarterly Journal of Economics, vol. 97(1), p 67-88. 
66. SIDDIQI F, PATRINOS A H (1995) Child Labor: Issues, Causes and Interventions. Washington D.C.: World Bank.

67. SILVERS J (1996) 'Child Labour in Pakistan', Atlantic Monthly Magazine, 277, vol No. 2, pp. 79-92.

68. THARENOU P, SAKS M, MOORE C (2007) ,A review and Critique of research on training and organisational-level outcomes', Human Resource Management Review, vol 17, p.251-273.

69. UNITED NATION CONVENTION ON THE RIGHTS OF THE CHILD (1989). United Nation Organization Geneva. http:// www.un.org/fileadmin/user_upload/Policy_ Dialogue/48th_I CE/CONFINTED_48-3 English.pdf. Retrieved on August, 20, 2013.

70. UNITED NATION EDUCATIONAL SCIENTIFIC AND CULTURAL ORGANIZATION (2006), (UIS: 2006) International Standard Classification of Education 1997. ISBN 92-9189-035-9 UIS/TD/06-01. www. uis.unesco.org. Retrieved June 4, 2013.

71. UNITED NATIONS EDUCATIONAL SCIENTIFIC AND CULTURAL ORGANIZATION (2008). Inclusive Education: The
Way of the Future, ED/BIE/CONFINTED 48/3 International Conference Centre, Geneva. http://www.ibe.unesco.org/fileadmin/ user_upload/Policy_Dialogue/48th_I. CE/ CONFINTED_48-3_English.pdf. Retrieved on October 14, 2013.

72. UNITED NATIONS, "CONVENTION ON THE RIGHTS OF THE CHILD,” http:// www2.ohchr.org/english/law/crc.htm\#art32. Retrieved on September 23, 2013.

73. UNITED NATIONS, "STATUS AS AT 23-09-2012. CONVENTION ON THE RIGHTS OF THE CHILD," http://treaties.un.org/Pages/ViewDetails.aspx?s$\mathrm{rc}=$ TREATY\&mtdsg_no=IV-11\&chapter $=4 \&$ lang $=$ en. Retrieved on September 23, 2013.

74. UNICEF (2102). At a Glance: Guatemala. http:/www.unicef.org/infobycountry/guatemala_statistics.html. Retrieved on October 8, 2013.

75. UNITED STATES DEPARTMENT OF LABOR (2012) Legislation and Enforcement Efforts. http://www.dol.gov/ilab/media/reports/iclp/sweat5/chap3.htm. Retrieved on September, 07, 2013. 